\title{
Csanád Bodó. 2016. Nyelvi ideológiák és különbségek [Language Ideologies and Differences]. Cluj-Napoca: Romanian Institute for Research on National Minorities.
}

\author{
Review by \\ Noémi FAZAKAS \\ Department of Applied Linguistics \\ Sapientia Hungarian University of Transylvania \\ galfnoemi@gmail.com
}

Over the past several decades, the study of language ideologies and attitudes towards languages has become increasingly popular in Hungarian sociolinguistic research. Several authors examine the issues of stereotypes, myths, and superstitions on language and language use, which exist in the collective consciousness of speakers of the Hungarian language about what correct language use is and what does not count as such.

Csanád Bodó's work entitled Language Ideologies and Differences attempts to carry out a somewhat different analysis: it discusses theoretical aspects of language ideologies in three sociolinguistic contexts, which he calls the "emblematic" areas of empirical studies. The author moves away from traditional sociolinguistic analyses towards the framework of critical sociolinguistics, in which language differences are seen as discursive projections of social inequalities that function as means to draw the boundaries of certain groups identified as linguistically dissimilar. The book itself aims to be a critique of constructing and maintaining differences, and as such it is about "minorities". The three contexts the author chooses to discuss are the Hungarian-speaking Moldavian - so-called Csángó - population in north-eastern Romania, ideologies addressing the language of women and Roma in Hungary, as well as the differences between the Hungarian language as spoken in Transylvania and Moldavia. The choice of these areas is not aleatory: Csanád Bodó was part of and led several research projects and wrote papers on the topics discussed, and as such this volume can be considered as a synopsis of his scholarly work, in which he reiterates, revisits, and reinterprets 
previous studies by bringing them closer to the most recent literature on the topic(s) entailed.

The volume is structured into 9 chapters. Chapter 1 gives an introduction to the study of language ideologies and differences: it starts with the definition of language ideologies in Silverstein's terms: “ideologies about language, or linguistic ideologies, are any sets of beliefs about language articulated by the users as rationalization or justification of perceived language structure and use" (Silverstein 1979: 193). The author also outlines the principles that organize the volume: language ideologies function as bridges between discursively interpreted social structures and phenomena of language use; language ideologies can always be attributed to someone; they are diverse and manifold, in which ideologies not always correspond with everyday practice; and, finally, language ideologies can be explicit and implicit, and researching them reveals their functions and the changes in these functions but also makes them "visible". The introductory chapter gives a short overview of the topics and issues examined in the following.

Chapter 2 entitled Language Ideologies in the Study of Language Varieties discusses theoretical and methodological aspects of the research of language varieties in the Hungarian scholarly literature, stating that the majority of such analyses has interpreted variety in the context of the "ideology of the standard language" (as defined my Milroy 2001). In the first, more theoretically focused part of the chapter, the author presents an overview of previous sociolinguistic research (mostly within the Labovian paradigm) regarding Hungarian language varieties, on the one hand; on the other, it iterates the critique of such standpoints that build upon the hegemony of the standard language ideology. The second part of the chapter focuses on the discussion of two varieties: the $(z s)$ variety in Moldavia and the $\left(-(A)_{s z}\right)$ variety of ikless verbs in the $8^{\text {th }}$ district of Budapest. These are not universally present in the Hungarian language community, and the author wishes to demonstrate that while the discourse about standard language is more or less present in the examined communities, the use of these particular standards is defined by factors different from the standard itself. The author concludes that local linguistic processes that function independently from the standard can serve both the increase and decrease of language diversity and that the research of language varieties needs to take into consideration the fact that the processes of indexicalization are embedded into local contexts and not necessarily in opposition with the standard.

Chapter 3, Linguistic Standards and Revitalisation, is built around the dilemma whether to connect language revitalization with standardization or not. According to Austin and Sallabank (2011), creating the standard is interpreted as the key to the survival of endangered languages; however, it also results in a hierarchy that inevitably causes the decrease of dialectal diversity as the standard is placed above all other varieties. The author analyses the process of creating such standards in 
the context of language revitalization, using the example of Moldavian Hungarian (Csángó) and demonstrating that following language standards results in the increase of diversity as it creates previously unknown forms of language use. The author tackles the issues of diversity and standardization in the Bakhtinian framework, stating that heteroglossia as a term - although not prevalent in the Hungarian scholarly literature - could be very useful in discussing diversity. He also differentiates standard language from linguistic standards, stating that every standard language gains its importance only in the practice of linguistic standards. The chapter contains a short description of the Hungarian language in Moldavia as well as that of the revitalization programme that aims at reviving the language through teaching it in and outside of school. The author presents the importance of performance, especially writing, and the ways new standards are created. The analysis focuses on the varieties of texts written by children published in the volume entitled A mi falunkban csángók laknak ("there are csángós living in our village”) and in their letters sent to the godparents who support them financially. The author concludes that heteroglossia needs to be interpreted within language performance and that the written texts created by the Moldavian children aiming at a target audience from Hungary become tools of commodifying the local language and language revitalization itself.

Chapter 4 entitled How Are Dialects Created? (The Enregisterment of Moldavian Hungarian) discusses aspects of the relationship between language and space, stating that dialects need to be "created" and "discovered" both as entities and as fields of study. The author turns to Johnstone to support this approach: according to him, "dialect boundaries are not inscribed on the landscape, so the world does not present itself to linguists with dialects waiting to be discovered" (Johnstone 2011: 3). The chapter presents a historical overview of the processes that resulted in the "creation" of the Moldavian Hungarian dialects from the point of view of the scholarly interest in the topic; this is followed by the general presentation of the Moldavian sociolinguistic context (using Vilmos Tánczos's data) as well as the results of the newest dialectometric analyses carried out by the author and his research team aiming to create a classification of the dialects of the region. In the last part of the chapter, the author applies the concepts of enregisterment (e.g. Agha 2003) and indexicality (Silverstein 2003) in outlining a theoretical model regarding the discursive development of dialects; it also presents a possible application of this model from the point of view of the "discovery" of the Csángó dialect.

Chapter 5 discusses representations of Hungarian dialects in the lay reactions to a linguistic education campaign entitled Nyelvjárás-projekt (The Dialect Project). The chapter starts with a presentation of the project itself (concise descriptions and representative videos on Transindex online portal featuring speakers from larger Transylvanian towns and dialect areas, reading the same text in their own 
variety). The author continues with the analysis of the comments under the videos with a special focus on the representations of the influence of the Romanian language in the Moldavian context. He also points out significant differences between the Transylvanian enregisterment of the Moldavian "Csángó" dialect and its enregisterment in Hungary, stressing the fact that the latter does not take into account the influence of the Romanian language.

In Chapter 6 (Implicit and Explicit Language Ideologies in Moldavia), the author presents the relationships between language varieties spoken in communities with other languages and varieties, focusing on the status of the Hungarian language. $\mathrm{He}$ also gives an outline of the attempts to explain the language shift in Moldavia and the ideologies connected to it. The theoretical aspects include the discussion of different types of language ideologies as well as possible approaches to ideologies based on the scholarly literature. Csanád Bodó discusses the intricate issue of the different ethnonyms and glottonyms used in the case of the Moldavian Hungarians (from the historical and geographical point of view), especially stressing the aspect of identity and identification, using the results of several empirical surveys as well as interviews conducted with locals. In presenting the ideologies of language shift, the author outlines patterns of bilingual socialization in Moldavia as well as ideologies that are implicitly or explicitly present in the discourses about language, language use, and the changes in the language repertoire.

Chapter 8 is built around the issue of language ideologies in the scientific classification of Gypsies in Hungary, the central factor of which is language itself. In this chapter, the author uses Irvine and Gal's model in discussing ideologies: according to this, "[L]inguistic features are seen as reflecting and expressing broader cultural images of people and activities" (Irvine-Gal 2000: 37). The chapter presents Kamill Erdős’s and István Kemény's classifications of the Gypsy communities living in Hungary and stresses the ways in which the latter became the canonical classification in Gypsy research. The author also includes a lesser known system, that of the Boyash categorization. The chapter concludes that the practice of such classifications is inseparable from language ideologies that stress the processes in which the iconic relationship between language and "folk" is interpreted in the context of hegemonic language ideologies.

The last thematic chapter discusses the gender paradox and its reception in Hungarian sociolinguistics. The author starts with outlining the difference between quantitative sociolinguistics, in which gender is used as a fixed identity, and the constructivist approaches, according to which the gender identity of the speaker is created by and within social practices. The author continues to present three aspects of the gender paradox as formulated by Labov: the case of stable sociolinguistic varieties, top-down as well as bottom-up changes. The author gives an overview of the international reception of the gender paradox together with some Hungarian aspects. 
In the short concluding chapter, the author reiterates the aims of the volume: to present the way language ideologies function in different sociolinguistic contexts, stating that language ideologies are universal yet diverse ideologies of groups and individuals; they, however, are not necessarily conscious. He also stresses the fact that the linguistic differences discussed in the scholarly literature are always social differences as well, and that is why it is important that linguistic examination becomes part of social negotiations. The volume includes several original maps, diagrams and figures, and a comprehensive bibliography: in all of these respects, one can recognize the author's ability to make use of results of previous research projects and reinterpret them in the light of newer theoretical works. The volume is another testimony of the author's familiarity with international sociolinguistic trends: in this book, Csanád Bodó succeeds in connecting familiar topics with concepts, terms, and trends that are less known in Hungarian sociolinguistics.

This volume is recommended to scholars and researchers working in the field of Hungarian sociolinguistics and interested in the latest trends in critical sociolinguistics, students of BA and MA programmes studying languages and linguistics but also non-linguists who are intrigued by the intricacies of linguistic diversity and the issues of bilingualism, dominant varieties, and language shift.

\section{References}

Agha, A. 2003. The social life of cultural value. Language and Communication 23: 231-273.

Austin, P. K.-Sallabank, J. (eds). 2011. The Cambridge handbook of endangered languages. Cambridge: Cambridge University Press.

Irvine, J.-Gal, S. 2000. Language ideology and linguistic differentiation. In: Kroskrity, P. V. (ed.), Regimes of language: ideologies, polities and identities. Santa Fe-New Mexico: School of American Research Press. 35-83.

Johnstone, B. 2011. Making Pittsburghese: communication technology, expertise, and the discursive construction of a regional dialect. Language and Communication 31: 3-15.

Milroy, J. 2001. Language ideologies and the consequences of standardization. Journal of Sociolinguistics 5: 530-555.

Silverstein, M. 1979. Language structure and linguistic ideology. In: Clyne, P. R.-W. F. Hanks-C. L. Hofbauer (eds), The elements: a parasession on linguistic units and levels. Chicago: Chicago Linguistic Society. 193-247.

2003. Indexical order and the dialectics of sociolinguistic life. Language and Communication 23: 193-229. 